\title{
Jordanian Evidence of the relationship between Agency Cost and Corporate Governance
}

\author{
Imad Zeyad Ramadan ${ }^{1}$ \\ ${ }^{1}$ Department of Finance, Applied Science Private University, Amman, Jordan \\ Correspondence: Imad Zeyad Ramadan, Full Prof., Department of Finance, Applied Science Private University, \\ P. O. Box 166, Amman, Jordan. E-mail: i_ramadan@asu.edu.jo
}

Received: May 1, 2016

doi:10.5539/mas.v10n10p160
Accepted: May 25, 2016

Online Published: July 27, 2016

URL: http://dx.doi.org/10.5539/mas.v10n10p160

\begin{abstract}
This study aimed to shed light on the role of corporate governance tools in mitigating the agency problem in the Jordanian industrial companies, through studying the effect of the internal corporate governance tools; the ownership structure, the board of directors and capital structure on the asset turnover rate as an inverse indicator to the agency costs.

The study concluded that the ownership structure in particular the firms ownership and ownership focus, the characteristics of the board of directors in terms of the number of members and members' independence, separation of the positions of chairman of the board of directors and chief executive officer of the company, in addition to bank loans as an indicator of capital structure constitutes tools for effective corporate governance in the Jordanian industrial companies.
\end{abstract}

Keywords: governance tools, agency costs, Jordan

\section{Introduction}

There are a lot of empirical studies that acknowledged that the financing decision and investment decision and thus the value of the firm are affected by the level of this inconsistency and lack of harmony. The implicit assumption of these studies was that in the absence of market efficiency, the agency problem is something realistic and adversely affects the value of the firm, and that there are a set of corporate governance tools, which are divided into internal and external tools, can alleviate this problem and its negative impact on the value of the firm.

In spite the fact that corporate governance rules are old, the need has become greater with the increasing exposure of cases of ill-management practices, which resulted in a lot of cases of the bankruptcy of major companies which affected the economy. The global financial crisis that began in 2006 represented these practices, as it strongly led towards the issuance of corporate governance laws which control and regulate the work of departments to maintain the interests of stakeholders in the company, and to prevent the occurrence of such problems in the future. The foundations of the rules of corporate governance have become one of the most important topics at the level of the economies of countries in the world, and have become an important element for the promotion of economic reform, and the evidence for the existence of the policy and rules for the protection of investors and dealers, as a means to promote confidence in the economy.

The study aimed at examining the relationship between corporate governance and agency cost of Jordanian industrial companies by measuring the impact of a set of governance variables on the asset turnover rate as an inverse alternative to agency cost.

This study seeks to add new evidences about the supposed relationship between corporate governance tools and agency cost in developing countries, namely Jordan, and this study completes previous studies that did not reach a consensus on the impact of corporate governance on the Agency costs, as an attempt to measure the impact of corporate governance variables on the Agency costs in less developed countries.

Ho: There is no statistically significant effect for corporate governance tools on managerial agency cost.

\section{Literature Review}

A study by Grossman and Hart (1982) and a study carried out by Jensen (1986) have concluded that borrowing 
reduces the flow of funds available to managers, leading to a reduction in the agency costs, where through the premiums payments borrowing reduce funds available to managers.

Moreover, borrowing contracts reduce managers' tendency towards excessive expansion in building their empires, leading to a reduction in agency costs, and increase the market value of the company. A study carried out by McConnell and Servaes (1995) confirmed this result and concluded that there is a strong correlation between the indebtedness of the company and its market value for companies with low growth rate.

On the other hand, the Corporate Governance studies have confirmed the relationship between the performance of the company and its ownership structure, whereas a study carried out by Morck et al. (1988) and a study carried out by McConnell and Servaes (1995) have confirmed that the management ownership of stocks is linked to a positive relationship with the company's strong performance at the low level of ownership, and that this relationship becomes inverse at high managerial ownership levels. A study carried out by Kole (1995) has shown that the positive relationship between management ownership and company's performance strongly appears at high ownership levels in small-sized firms. Jensen and Meckling (1976) and Myers (1977) have concluded that there was a statistically significant inverse relationship between management ownership and agency costs, while Hiraki et al. (2003) and Chen et al. (2003) have indicated a strong positive relationship between ownership management and Tobin's q index. A study carried out by Ehikioya (2009) has shown a statistically significant positive relationship between senior shareholders' ownership rate and company's profitability in Nigerian companies, while a study carried out by Aikleny (2004) has concluded a positive relationship for organizational investor's ownership rate on the performance of Malaysian companies.

\section{Data and Methodology}

\subsection{Study Variables}

\subsubsection{Dependent Variable: Agency Costs (AG_C)}

Agency Cost is expressed by the assets turnover rate as inverse index of agency cost. In line with Ang et al. (2000) and Sign and Davidson (2003) asset turnover rate is calculated by the ratio of annual sales to total assets, and the reason for the low rate of turnover of assets can be seen as bad investment decisions, Insufficient management's effort and the purchase of non-productive assets, and it is expected that the companies of low assets turnover rate may face high managerial agency costs between managers and shareholders.

\subsubsection{Independent Variables}

The study model includes eight independent variables related to corporate governance: Ownership structure, Board of Directors and Capital structure as follows:

- Companies equity ratio (C_EQ) which is a percentage of the total shares owned by the companies to the paid-up capital of the company.

- Ownership concentration (L_OW) which is a ratio of stock owned by the major shareholders to the paid-up capital of the company on the grounds that major shareholders are those who own $7 \%$ or more of the company's shares.

- Foreign ownership ratio (F_OW) which is the ratio of shares owned by non-Jordanian to the paid-up capital of the company.

- The number of members of the Board of Directors (B_SIZ)

- The number of non-executive members in the Board of Directors (B_IN) which is the percentage of non-executive members and who have no personal interests with the company to all the members of the Board of Directors.

- Combination between the Chairman of the Board of Directors and Chief Executive Officer (CEO_DU). (Dummy Variable) was used for the combination between the Chairman of the Board of Directors and Chief Executive Officer, so that the value 1 is given if there is no separation between the two positions and the value 0 for otherwise, in line with previous studies.

- Bank loans (B_LO) which is bank loans to total loans.

- Short-term loans (S_DB) which is the proportion of short-term liabilities to total liabilities.

In addition to the eight independent variables two control variables were used, the company size (SIZ), expressed in company's total assets, and company's rate of growth expressed by market value ratio to book value per company's share (M_B). 
Based on the foregoing, study model can be written as follows:

$$
\begin{aligned}
A G_{-} C_{i t}=\alpha+\beta_{1} C_{-} E Q_{i t}+\beta_{2} L_{-} O W_{i t} & \beta_{3} F_{-} O W_{i t}+\beta_{4} B_{-} S I Z_{i t}+\beta_{5} B_{-} I N_{i t}+\beta_{6} C E O_{-} D U_{i t}+\beta_{7} B_{-} L O_{i t}+ \\
& \beta_{8} S_{-} D B_{i t}+\beta_{9} S I Z_{i t}+\beta_{10} M_{-} B_{i t}+\varepsilon
\end{aligned}
$$

Where: $A G_{-} C$ is the agency cost of the company expressed as the inverse ratio of the assets turnover; $i$ and $t$ are the $i^{\text {th }}$ cross-sectional firm at $t^{\text {th }}$ period ; $\alpha$ is a constant term; $\beta^{\prime s}$ the slope coefficients to be estimated; C_EQ is the companies' equity ratio; L_OW is the ownership concentration; F_OW is the foreign ownership; B_SIZ is the board size; B_IN is the number of non-executive members in the board of directors; CEO_DU is a dummy variable used for the combination between the chairman of the board of directors and chief executive officer; B_LO is the bank loans; S_DB is the short-term loans; SIZ is the company's size; M_B is the company's rate of growth and $\varepsilon$ is the random error.

\section{Results}

Using Multivariate analysis and Cross-Sectional Regression the effects of corporate governance tools on assets turnover rate as an inverse alternative of agency costs were studied. Table 1 shows the analysis of corporate governance tools of the assets turnover rate as an inverse alternative of agency costs in presence of two control variables and by using equation (1).

The results indicate that for the ownership structure the coefficient of ownership rate was positive, and this means that there is a positive relationship between the percentage of ownership of companies and asset turnover rate as an inverse alternative to the agency costs, and that this relationship is statistically significant at the significance level of 0.1 . This means that the increase in the proportion of corporate ownership leads to a reduction in agency costs.

In Table 1 results indicate that the percentage of foreign ownership is linked by a positive relationship with the asset turnover rate, and thus work to reduce agency costs, but this relationship is not statistically significant at the significance level 0.1 and as for the percentage of ownership of senior shareholders (ownership concentration), the results indicate a statistically significant positive relationship at the significance level 0.01 , which means that the ownership concentration is one of corporate governance tools that statistically work in reducing the managerial agency costs between management and shareholders.

As for the characteristics of the Board of Directors, Table 1 shows that the regression coefficient B_SIZ was negative, which means that there is a negative relationship between the number of members of the board of directors and the rate of turnover of assets as an inverse alternative to the agency costs, which means that the lack of number of board members leads to increased turnover assets, and thus lack of agency costs. For B_IN regression coefficient was positive, indicating a positive relationship between the independent members of the board of directors and the rate of turnover of assets, so that an increase in the proportion of independent members in the board leads to a reduction of managerial agency costs. Also, the study showed that the regression coefficient CEO_DU was negative, which means that the separation between the two positions leads to improve asset turnover and thus to reduce agency costs.

Table 1. Regression results

\begin{tabular}{ll}
\hline Constant & 1.03 \\
& $(1.287)$ \\
C_EQ & 0.287 \\
& $(1.751)^{* * *}$ \\
F_OW & 0.257 \\
& $(1.183)$ \\
L_OW & 0.917 \\
& $(2.991)^{*}$ \\
B_SIZ & -0.379 \\
& $(-1.846)^{* * *}$ \\
B_IN & 0.691 \\
& $(1.671)^{* * *}$ \\
CEO_DU & -0.287 \\
& $(-1.739)^{* * *}$ \\
\hline
\end{tabular}




\begin{tabular}{ll}
\hline B_LO & 0.219 \\
& $(2.061)^{* *}$ \\
S_DB & 1.874 \\
& $(1.359)$ \\
SIZ & 0.286 \\
& $(1.994)^{* *}$ \\
M_B & -0.397 \\
& $(-3.781)^{*}$ \\
F & 16.987 \\
R & 0.383 \\
\hline
\end{tabular}

Definition of the variables are within the variables of the study, *,**, *** indicate a significant level of $1 \%, 5 \%$, $10 \%$.

Table 1 also shows that the inverse relationship between asset turnover rate and each of B_SIZ, CEO_DU, and B_IN was statistically significant at significance level $\alpha<0.1$.

As for the capital structure, one of the Corporate Governance tools, the results of the study indicated that the loan source plays an important role in reducing agency costs, whereas Table 1 shows that the regression coefficient of B_LO was positive and statistically significant at a significance level $<0.05$, while results did not show any statistical significance of the impact of S_DB on agency costs.

Accordingly, the results suggested that the increase of the ownership of major shareholders ratio reduces agency costs with a statistical significance at the significance level of 0.01 , and that the increase in bank loans reduces agency costs with a statistical significance at the significance level 0.05 , also, the increase of the proportion of the contribution of companies and the increase of the proportion of independent members of the board of directors reduce agency costs at the significance level 0.1 .

The study also showed that the decline in the number of members of the board of directors and the separation between the positions of the chairman of the board of directors and chief executive officer of the company's are of the corporate governance tools with statistical significance at the significance level 0.1 in reducing agency costs.

The study indicated that the control variables coefficients: company's size and growth rate of the company were positive and negative respectively, which means that small companies, companies with a high growth rate have agency problems between management and shareholders more than the big companies and the low rate growth companies with a statistical significance at significance level 0.05 and 0.01 respectively.

Finally, the results of the multi-covariance analysis suggest that corporate ownership ratio and the percentage of ownership of major shareholders are effective tools in mitigating agency costs, and that the low number of board members and the increase of the number of the independent members of the board of directors, as well as the separation between chairman and CEO positions reduce agency costs.

\section{Acknowledgements}

The author is grateful to the Applied Science Private University, Amman, Jordan, for the financial support granted to this research project (Grant No. DRGS-2015-2016-66).

\section{References}

Aik Leng, A. (2004). The impact of corporate governance practices on firms' financial performance: Evidence from Malaysian companies. SEAN Economic Bulletin, 21, 308. http://dx.doi.org/10.1355/AE21-3D

Ang, J. S., Cole, R. A., \& Lin, J. W. (2000). Agency costs and ownership structure. Journal of Finance, 55, 81-106. http://dx.doi.org/10.1111/0022-1082.00201

Chen, C. (2003). Investment opportunities and the relation between equity value and employees' bonus. Journal of Business Finance and Accounting, 30, 941-74. http://dx.doi.org/10.1111/1468-5957.05346

Ehikioya, B. (2009). Corporate governance structure and firm performance in developing economies: evidence from Nigeria. Corporate Governance Journal, 9(3), 231-243. http://dx.doi.org/10.1108/14720700910964307

Grossman, S., \& Hart, O. (1986). The cost and benefits of ownership: A theory of vertical and lateral integration. Journal of Political Economy, 94, 691-791. http://dx.doi.org/10.1086/261404 
Hiraki, T., Inoue, H., Ito, A., Kurokif, \& Masuda, H. (2003). Corporate Governance and Firm Value in Japan: Evidence from 1985-1998. Pacific-Basin Finance Journal, 11, 239-265. http://dx.doi.org/10.1016/S0927-538X(03)00023-4

Jensen, M. (1986). Agency Cost of free Cash Flows, Corporate Finance and Takeovers. American Economic Review-Papers and Proceedings (76).

Kole, S. (1995). Measuring Managerial equity ownership a Comparison of Sources of ownershio data. Journal of Corporate Finance, 1, 413-435. http://dx.doi.org/10.1016/0929-1199(94)00012-J

McConnell, J. J., \& Servaes, H. (1995). Equity ownership and the two faces of debt. Journal of Financial Economics, 39, 131-157. http://dx.doi.org/10.1016/0304-405X(95)00824-X

Morck, R., Shleifer, A., \& Vishny, R. W. (1988). Management ownership and market valuation: An empirical analysis. Journal of Financial Economics, 20, 293-315. http://dx.doi.org/10.1016/0304-405X(88)90048-7

Myers, S. (1977). Determinants of corporate borrowing. Journal of Financial Economics, 5, $147-175$. http://dx.doi.org/10.1016/0304-405X(77)90015-0

Singh, M., \& Davidson, W. N. III (2003). Agency costs, ownership structure and corporate governance mechanisms. Journal of Banking \& $\quad$ Finance, $\quad 27, \quad 793-816$. http://dx.doi.org/10.1016/S0378-4266(01)00260-6

\section{Copyrights}

Copyright for this article is retained by the author(s), with first publication rights granted to the journal.

This is an open-access article distributed under the terms and conditions of the Creative Commons Attribution license (http://creativecommons.org/licenses/by/4.0/). 